\title{
Nitrate and potassium concentration in fertigated soil cultivated with wine vines
}

\author{
Concentração de nitrato e potássio em solo fertirrigado \\ e cultivado com videira de vinho
}

\author{
Alexsandro Oliveira da Silva ${ }^{1 \star}$, Davi José Silva ${ }^{2}$, Luis Henrique Bassoi ${ }^{3}$ \\ 'Universidade Federal Rural de Pernambuco/UFRPE, Engenharia Agrícola, Recife, PE, Brazil \\ ${ }^{2}$ Empresa Brasileira de Pesquisa Agropecuária/Embrapa Semiárido, Petrolina, PE, Brazil \\ ${ }^{3}$ Empresa Brasileira de Pesquisa Agropecuária/Embrapa Instrumentação, São Carlos, SP, Brazil \\ *Corresponding author: alexsandro_oliveira01@hotmail.com \\ Received in november 15, 2015 and approved in January 8, 2016
}

\begin{abstract}
In the semiarid region of Brazil the use of irrigation systems for applying fertilizers in horticulture is the primary means for incorporating nutrients in the soil. However, this technique still requires its use in wine vines to be assessed. In view of this, this study aimed to assess nitrate and potassium concentrations in soil fertigated with nitrogen and potassium fertilizers in 3 wine grape growing cycles. A field experiment was conducted with 'Syrah' wine grapes, in Petrolina, Pernambuco, Brazil; it assessed five nitrogen doses $\left(0,15,30,60\right.$ and $\left.120 \mathrm{~kg}^{-1}\right)$ and five $\mathrm{K}_{2} \mathrm{O}$ doses $\left(0,15,30,60\right.$ and $\left.120 \mathrm{~kg} \mathrm{ha}^{-1}\right)$ applied by drip irrigation system with two emitters per plant, with a flow rate of $4 \mathrm{~L} \mathrm{~h}^{-1}$. The experimental design used was the factorial split-plot, making up 13 combinations arranged in 4 randomized blocks. Soil solution samples were collected weekly with the aid of porous cup extractors for all treatments and at depths of 0.4 and $0.6 \mathrm{~m}$ by determining nitrate and potassium concentrations and electrical conductivity. Increased levels of both nutrients in the irrigation water increased the availability of nitrate and potassium in the soil solution. The highest nitrate and potassium concentrations were found in the second growing cycle at both depths studied.
\end{abstract}

Index terms: Vitis vinifera L.; soil solution; fertigation.

\section{RESUMO}

No Semiárido do Brasil com o advento da irrigação na fruticultura, o aproveitamento destes sistemas para o uso da fertirrigação é um dos principais meios para a incorporação de nutrientes no solo. Porém, esta técnica ainda requer avaliações sobre seu uso, manejo e sistemas de aplicação. Diante disto, esse trabalho teve como objetivo avaliar a concentração de nitrato e potássio em solo fertirrigado com fertilizantes nitrogenados e potássicos em cultivo de videira de vinho. Foi realizado um experimento de campo com videiras 'Syrah', em Petrolina-PE, sendo avaliados cinco doses de nitrogênio $\left(0,15,30,60\right.$ e $\left.120 \mathrm{~kg} \mathrm{ha}^{-1}\right)$ e cinco doses de $\mathrm{K}_{2} \mathrm{O}(0,15,30,60$ e $120 \mathrm{~kg}$ ha-1), em esquema fatorial fracionado, perfazendo 13 combinações, dispostas no delineamento blocos casualizados com quatro repetições, aplicadas via fertirrigação. A irrigação foi realizada por gotejamento com dois emissores por planta com vazão de $4 \mathrm{~L} \mathrm{~h}^{-1}$. Amostras de solução do solo foram coletas semanalmente em todos os tratamentos nas profundidades de 0,4 e 0,6 m, determinando-se a concentração de nitrato, de potássio e a condutividade elétrica. Os resultados permitiram concluir que o aumento da concentração de nitrogênio e potássio na água de irrigação aumentou a disponibilidade de nitrato e potássio na solução do solo. As maiores concentrações de nitrato e potássio foram observadas no segundo ciclo de produção da cultura da videira em ambas as profundidades estudadas.

Termos para indexação: Vitis vinifera L.; solução do solo; fertirrigação.

\section{INTRODUCTION}

The vine has different nutritional needs depending on weather, rootstock, variety of canopies, conduction system and soil, as well as specific needs of each nutrient in its different phenological phases (Sousa et al., 2011). For this reason, knowing the nutritional requirements of this crop is of great importance for increasing productivity and improving the quality of grapes (Rocha; Bassoi; Silva, 2015). In the semiarid region of Brazil, with the advent of irrigation in fruit farming, using these systems in fertigation is a major means for incorporating nutrients in the soil, having as advantage reduced workforce, flexibility in application and the efficiency of its use (Cunha et al., 2014). The efficiency of fertigation involves the assessment of the irrigation system in relation to its water application efficiency and uniformity (Cunha et al., 2014), and the monitoring of the application of fertilizers; additionally, one should know the concentration of the latter from the injection moment (Coelho; Andrade Neto; Barros, 2014; Nesthed et al., 2013), until the condition of the nutrients 
in the soil (Coelho et al., 2014), which can be done through the monitoring of the soil solution via porous cup extractors (Silva et al., 2014).

Among the sources of fertilizers applied via fertigation, urea is one of the most soluble among nitrogen fertilizers and among potassium fertilizers, potassium chloride, potassium nitrate and potassium sulfate. Nitrogen is the nutrient most frequently used in vine fertigation (Sousa et al., 2011), in which the $\mathrm{N}$ available for plants is dependent on the amount of organic matter in the soil, soil type, soil aeration, temperature and water content in the soil. Potassium is the second nutrient most frequently used in fertigation, mainly in the form of potassium sulfate, being important in the lignification of branches and in the ripening of the fruits of this crop (Terra, 2001).

In studies about fertigation, one of the essential factors for the proper management of the fertilizers applied during the growing season is the movement of soil nutrients, because the optimization of fertigation depends on the availability of nutrients at the depth of maximum density of the root system, avoiding leaching into the water table and, therefore, into springs and rivers (Ramos et al., 2011). Nitrogen is an essential element for the survival of plants, but its behavior is quite dynamic in the soil. In agricultural systems, N sources are: atmospheric deposition, nitrogen fertilization (Rocha; Bassoi; Silva, 2015), biological fixation of atmospheric $\mathrm{N}_{2}$, and mineralization of the organic $\mathrm{N}$ of the soil (Siqueira Neto et al., 2010). Although N can be absorbed by plants as anion $\left(\mathrm{NO}_{3}\right)$ and cation $\left(\mathrm{NH}_{4+}\right)$, its absorption in the form of $\mathrm{NO}_{3-}$ is faster because it travels through the soil solution until reaching the roots of the plants via mass flow, and its leaching can also occur with greater ease due to excess of water (Araújo et al., 2004). According to Zanini, Villas Bôas and Feitosa Filho (2002), potassium movement depends on the type of soil and, in most cases, is limited. In soils with low cation exchange capacity this nutrient may be leached, but when adequate doses of fertilizer are applied, losses by leaching are extremely low for most conditions. Also according to these authors, $\mathrm{K}$ can move through the soil profile when there is concentration of the element close to the emitters of the irrigation system.

The objective of this study was to assess nitrate and potassium concentrations in soil fertigated with nitrogen and potassium fertilizers in wine vine cultivation in the Brazilian semiarid region.

\section{MATERIAL AND METHODS}

The experiment was conducted in the Experimental Field of Bebedouro at Embrapa Tropical Semi-Arid, in
Petrolina, Pernambuco, Brazil, located at latitude S $09^{\circ}$ 08' 08, 09', longitude W $40^{\circ} 18^{\prime} 33.6^{\prime \prime}$ and at an altitude of $373 \mathrm{~m}$. The wine vine (Vitis vinifera L.), Syrah cultivar, was grafted on to the 1103 Paulsen rootstock. The planting was carried out on April 30, 2009, with spacing of $1 \mathrm{~m}$ between plants and $3 \mathrm{~m}$ between rows in trellis system. The vine training period lasted until the month of April 2010, when the first production pruning occurred. The three production prunings of this study were held on June 17, 2013, February 7, 2014 and August 6, 2014. The harvests happened on October 8, 2013, June 9, 2014 and November 25, 2014, totaling 113, 122 and 111 days after production pruning (dapp), respectively. The soil was classified as Argissolo Vermelho-Amarelo Eutrófico plintossólico (Typic Plinthustalf) of sandy loam texture, with $741.1 \mathrm{~g} \mathrm{k} \mathrm{g}^{-1}$ sand, $163.7 \mathrm{~g} \mathrm{k} \mathrm{g}^{-1}$ silt and $95.1 \mathrm{~g} \mathrm{k} \mathrm{g}^{-1}$ clay. The moisture level corresponding to the field capacity and to the permanent wilting point was $0.18 \mathrm{~m}^{3} \mathrm{~m}^{-3}$ and $0.10 \mathrm{~m}^{3} \mathrm{~m}^{-3}$, respectively. The chemical properties of the soil, obtained in the beginning of the experiment (Table 1), were assessed at depths of $0.2,0.4$ and $0.6 \mathrm{~m}$.

The treatments consisted of five doses of nitrogen $\left(0,15,30,60\right.$ and $\left.120 \mathrm{~kg} \mathrm{ha}^{-1}\right)$ and five doses of $\mathrm{K}_{2} \mathrm{O}$ $\left(0,15,30,60\right.$ and $\left.120 \mathrm{~kg} \mathrm{ha}^{-1}\right)$. These treatments were combined in a $5^{2}$ split-plot factorial design (Little; Mott, 1975), totaling 13 combinations. The study was arranged in randomized blocks with four replications. Nitrogen and potassium was supplied as urea, potassium nitrate, chloride and sulfate, applied via fertigation. The accompanying ions were balanced by additional fertilization. The experimental unit (EU) was composed of 17 plants. The water depth was applied daily based on the crop evapotranspiration (ETc, $\mathrm{mm}$ ) determined by the product between the reference evapotranspiration (ETo, $\mathrm{mm}$ ) determined by the PenmanMonteith (Allen et al., 1998) and with meteorological data measured in automatic station installed $60 \mathrm{~m}$ from the experiment and the crop coefficient $(\mathrm{kc})$ obtained in the experimental area for 'Syrah' vines (Bassoi et al., 2007).

The drip irrigation system was used; each experimental unit had polyethylene hoses measuring 17 meters, controlled by an in-line valve that was opened at every fertigation event. The suction system consisted of a pipe with 6 meters in length that reached the water tank, an hydraulic motor pump set with flow rate of $15 \mathrm{~m}^{3} \mathrm{~h}^{-1}$, disk filter, injection pump and a $60 \mathrm{~L}$ tank for use in fertigation. The total flow rate required for the experiment was $8.81 \mathrm{~m}^{3} \mathrm{~h}^{-1}$, obtained through the flow rate test on the emitters in 5-minute intervals, with average flow rate of $3.6 \mathrm{~L} \mathrm{~h}^{-1}$. In the three growing cycles, tests to assess the Christiansen's uniformity coefficient (CUC), the emission uniformity (EUi), the absolute emission uniformity (AEU), 
the statistical uniformity (Us) and the system application efficiency (Ea) were performed according to methodology contained in Favetta and Botrel (2001). The fertilizer injection time was estimated through an injection test on the system itself by means of electrical injection pump and using the highest fertilizer dosage in the tank $\left(17.51 \mathrm{~g} \mathrm{~L}^{-1}\right)$ corresponding to the joint application of doses of $120 \mathrm{~kg} \mathrm{ha}^{-1}$ of $\mathrm{N}$ and $120 \mathrm{~kg} \mathrm{ha}^{-1} \mathrm{~K}_{2} \mathrm{O}$ in the respective plots, in accordance with Zanini, Villas Bôas and Feitosa Filho (2002).

To determine the uniformity of the fertilizers, a simulation was performed using the treatments to be employed during the experiment regarding the weekly application, assessing the distribution of the fertilizers in relation to the distance of the emitters along the drip irrigation line, and the time after injection. The fertilizer application in the three growing cycles consisted of fertilizer dilution in the tank for injection whose sources were urea $(46 \% \mathrm{~N})$ and potassium nitrate $(12 \% \mathrm{~N})$ in 5 concentrations $\left(0 ; 1.60 ; 2.04 ; 4.66\right.$ and $\left.8.35 \mathrm{~g} \mathrm{~L}^{-1}\right)$ and potassium fertilizers in 5 concentrations $\left(0 ; 1.60 ; 2.04 ; 4.66\right.$ and $\left.8.35 \mathrm{~g} \mathrm{~L}^{-1}\right)$ whose sources were potassium sulfate $\left(50 \% \mathrm{~K}_{2} \mathrm{O}\right)$, potassium chloride $\left(60 \% \mathrm{~K}_{2} \mathrm{O}\right)$ and potassium nitrate $\left(45 \% \mathrm{~K}_{2} \mathrm{O}\right)$, making up the 13 combinations described above. The distance of the emitters from the beginning of the drip irrigation line was $0,6,12$ and $18 \mathrm{~m}$ and the time after injection was 5, 20 and 30 minutes. After the injections of each fertilizer were fully introduced into the system, $50 \mathrm{ml}$ aliquots of fertigated solution were collected from plastic containers installed along the drip irrigation lines and below the emitters at the different times assessed. After collection, the electrical conductivity of these solutions was determined with a benchtop conductivity meter in the Soil, Water and Plant Analysis Laboratory of Embrapa Tropical Semi-Arid.

The movement of nitrate and potassium ions in the soil was monitored weekly with the aid of porous cup solution extractors (Souza et al., 2013; Silva et al., 2003 ) installed 0.4 and $0.6 \mathrm{~m}$ deep in the plant row in all treatments and in three blocks ( 49 batteries with 78 porous cup extractors). A vacuum of $-80 \mathrm{kPa}$ was applied one day after fertigation. The soil solution was extracted 24 hours after each fertigation event. The nitrate concentration in the soil solution was determined by means of a card specific for determining nitrate concentration, according to Silva et al. (2003), whereas potassium concentration was determined by flame photometry. Alongside the extractors, tensiometers were installed $0.40,0.60 \mathrm{~m}$ deep to determine the soil moisture at the moment of the extraction of the soil solution for correcting the latter in relation to the moisture of the saturated paste. Prior to the experiment, soil samples were collected to determine the moisture of the saturated paste (Souza et al., 2013) in each experimental unit; such value was taken as reference and used to correct the values of nitrate $\left(\mathrm{NO}_{3}\right)$, potassium $\left(\mathrm{K}^{+}\right)$and electrical conductivity (EC) in the soil solution, obtained by the porous cup extractors, as performed by Silva et al. (2003).

The data obtained was subjected to analysis of variance $(\mathrm{F}$ test $)$ at $1 \%(0.01<\mathrm{p})$ and $5 \%(0.05<\mathrm{p})$ probability level. The variables with significant results were subjected to regression analysis at $1 \%$ and $5 \%$ level, using the software $\mathrm{R}^{\circledR}$ 2.8.0 version (R Development Core Team, 2012).

Table 1: Chemical characteristics of the soil of the experimental area before the application of the treatments.

\begin{tabular}{|c|c|c|c|c|c|c|c|c|c|}
\hline \multirow{2}{*}{$\begin{array}{l}\text { Depth. } \\
\text { (m) }\end{array}$} & \multirow{2}{*}{$\begin{array}{c}\mathrm{EC} \\
\mathrm{dS} \mathrm{m}^{-1}\end{array}$} & \multirow{2}{*}{$\begin{array}{l}\mathrm{pH} \\
\mathrm{H}_{2} \mathrm{O} \\
\end{array}$} & \multirow{2}{*}{$\begin{array}{l}\text { O.M. } \\
\mathrm{g} \mathrm{dm}^{-3}\end{array}$} & NO3- & $\mathrm{NH} 4+$ & \multirow{2}{*}{$\begin{array}{c}P \\
m g d^{-3}\end{array}$} & K & $\mathrm{Ca}$ & $\mathrm{Mg}$ \\
\hline & & & & $---m$ & $\begin{array}{ll}g^{-1}---- \\
\end{array}$ & & \multicolumn{3}{|c|}{$\mathrm{cmol}_{\mathrm{c}} \mathrm{dm}^{-3}$} \\
\hline $0-0.20$ & 0.70 & 7.50 & 20.8 & 4.28 & 4.86 & 156.9 & 0.9 & 3.5 & 1.3 \\
\hline $0.20-0.40$ & 0.50 & 7.21 & 15.2 & 3.50 & 4.67 & 123.9 & 0.6 & 3.1 & 1.1 \\
\hline $0.40-0.60$ & 0.32 & 6.81 & 8.9 & 3.11 & 4.08 & 93.79 & 0.4 & 2.8 & 1.1 \\
\hline \multirow{2}{*}{$\begin{array}{c}\text { Depth } \\
(\mathrm{m})\end{array}$} & $\mathrm{Na}$ & $\mathrm{H}+\mathrm{Al}$ & SB & CEC & \multirow{2}{*}{$\begin{array}{c}\mathrm{V} \\
(\%)\end{array}$} & $\mathrm{Cu}$ & $\mathrm{Fe}$ & $\mathrm{Mn}$ & $\mathrm{Zn}$ \\
\hline & \multicolumn{4}{|c|}{------cmol $\mathrm{dm}^{-3}$} & & \multicolumn{4}{|c|}{----------'mg dm³------- } \\
\hline $0-0.20$ & 0.10 & 1.1 & 5.8 & 7.0 & 83.3 & 1.75 & 18.08 & 61.6 & 21.5 \\
\hline $0.20-0.40$ & 0.10 & 1.3 & 4.9 & 6.2 & 78.8 & 2.49 & 19.63 & 46.4 & 19.8 \\
\hline $0.40-0.60$ & 0.08 & 1.4 & 4.4 & 5.8 & 75.7 & 4.71 & 23.02 & 26.9 & 12.2 \\
\hline
\end{tabular}

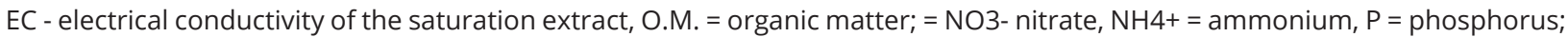
$\mathrm{K}=$ potassium; $\mathrm{Ca}=$ calcium; $\mathrm{Mg}=$ magnesium; $\mathrm{Na}=$ sodium, $\mathrm{H}+\mathrm{Al}=$ potential acidity; $\mathrm{SB}=$ sum of bases; $\mathrm{CEC}=$ cation exchange capacity; $\mathrm{V}(\%)=$ base saturation, $\mathrm{Cu}=$ copper, $\mathrm{Fe}=$ iron, $\mathrm{Mn}=$ manganese, $\mathrm{Zn}=$ zinc. 


\section{RESULTS AND DISCUSSION}

The dispersion analysis of the data showed an increase in electrical conductivity values in the irrigation water $(\mathrm{ECW})$ as $\mathrm{N}$ and $\mathrm{K}_{2} \mathrm{O}$ doses increased (Figure 1) in each application of the injection solution. For the emitter at the distance of $0 \mathrm{~m}$ (Figure 1A) from the beginning of drip irrigation line, it was observed that for the combination of potassium and nitrogen concentrations of $8.35 \mathrm{~g} \mathrm{~L}^{-1}$ the ECW showed a value of 6.64 $\mathrm{dS} \mathrm{m} \mathrm{m}^{-1}$, while in the lower concentrations in the injected solution of $\mathrm{K}_{2} \mathrm{O}$ and $\mathrm{N}\left(1 \mathrm{~g} \mathrm{~L}^{-1}\right)$ analyzed separately, the values were $0.33 \mathrm{dS} \mathrm{m}^{-1}$ and $0.37 \mathrm{dS} \mathrm{m}^{-1}$. In the emitters located at $6 \mathrm{~m}$ (Figure $1 \mathrm{~B}$ ) the smallest $\mathrm{ECW}$ values were observed in levels of $0 \mathrm{~g} \mathrm{~L}^{-1} \mathrm{~N}$ and $2 \mathrm{~g} \mathrm{~L}^{-1} \mathrm{~K}_{2} \mathrm{O}$ with 0.11
$\mathrm{dS} \mathrm{m} \mathrm{m}^{-1}$ and $7.58 \mathrm{dS} \mathrm{m}^{-1}$ for the concentrations of $8 \mathrm{~g} \mathrm{~L}^{-1}$ for $\mathrm{K}_{2} \mathrm{O}$ and $\mathrm{N}$. For the emitter located at the distance of $12 \mathrm{~m}$ (Figure 1C), the increase in the $\mathrm{ECW}$ with the increase in the fertilizers in the injected solution showed maximum values of $6.91 \mathrm{dS} \mathrm{m}^{-1}$ for the concentrations of $8 \mathrm{~g} \mathrm{~L}^{-1} \mathrm{~N}$ and $\mathrm{K}_{2} \mathrm{O}$, while for emitters located at $18 \mathrm{~m}$ (Figure 1D) the maximum ECW values were $7.33 \mathrm{dS} \mathrm{m}^{-1}$.

According to Coelho, Andrade Neto and Barros (2014) and Coelho et al. (2014), the increased fertilizer doses in the injected solution, besides increasing ECw, contributes significantly to increasing the concentrations of the fertilizers applied to the soil, as nitrate and potassium. These results are similar to those observed by Cunha et al.

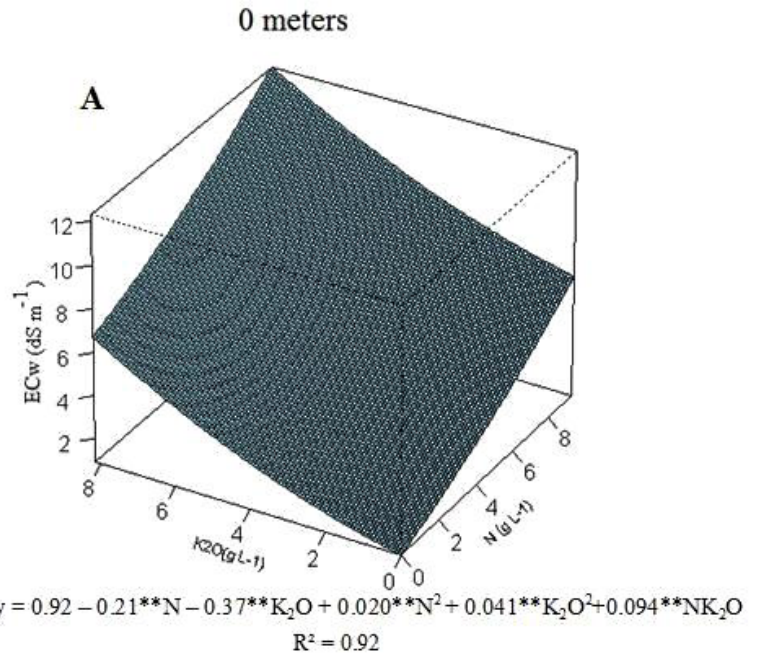

12 meters

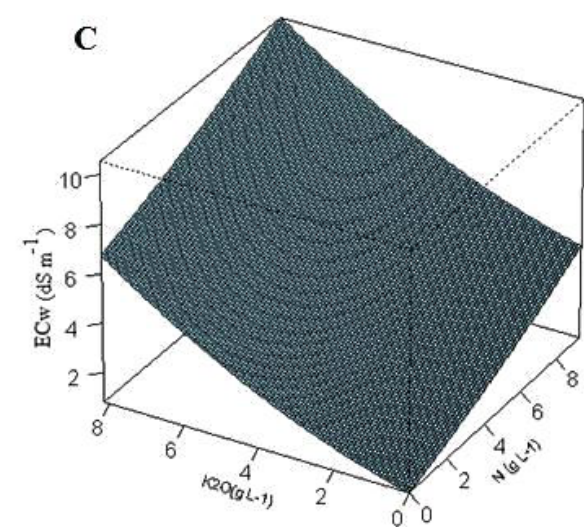

$\mathrm{y}=0.79-0.37^{* *} \mathrm{~N}-0.37 * * \mathrm{~K}_{2} \mathrm{O}+0.0098^{*} \mathrm{~N}^{2}+0.043^{* *} \mathrm{~K}_{2} \mathrm{O}^{2}+0.099^{* *} \mathrm{NK}_{2} \mathrm{O}$ $\mathrm{R}^{2}=0.90$

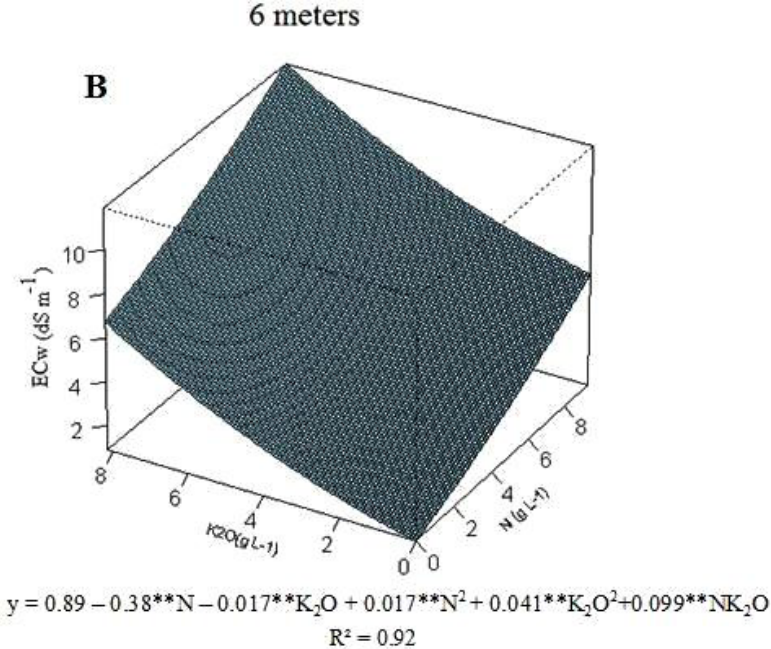

18 meters

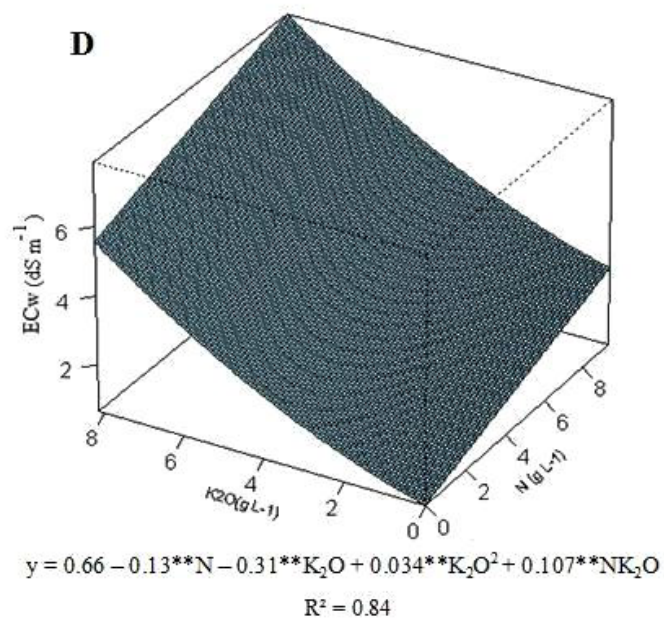

Figure 1: Analysis of dispersion of electrical conductivity in the irrigation water (ECw) subjected to different fertilizer doses along the drip irrigation line at distances of $0 \mathrm{~m}$ (A), $6 \mathrm{~m}$ (B), $12 \mathrm{~m}$ (C) and $18 \mathrm{~m}$ (D).

** and * significant at 1 and $5 \%$ by t test respectively. 
(2014) in studies about the uniformity of fertilizers under a subsurface drip irrigation system.

Regarding ECw in the different times of fertilizer application into the irrigation system after complete injection of fertilizer solution, the highest $\mathrm{ECW}$ values were observed for the highest fertilizer concentrations in all times studied. For data obtained at the time of 5 minutes after injection (Figure 2A), there were $\mathrm{ECw}$ values between 0.13 $\mathrm{dS} \mathrm{m} \mathrm{m}^{-1}$ and $6.68 \mathrm{dS} \mathrm{m}^{-1}$ for lower $\left(1 \mathrm{~g} \mathrm{~L}^{-1} \mathrm{~N}\right.$ and $\left.\mathrm{K}_{2} \mathrm{O}\right)$ and higher $\left(8.35 \mathrm{~g} \mathrm{~L}^{-1} \mathrm{~N}\right.$ and $\left.\mathrm{K}_{2} \mathrm{O}\right)$ fertilizer concentrations in the injector solution, respectively. For the time of 20 minutes after injection (Figure 2B), the fertilizer concentrations in the injector solution mentioned above showed $\mathrm{ECW}$ values between 0.24 and $7.99 \mathrm{dS} \mathrm{m}^{-1}$; but a smaller influence of potassium fertilizers on the $\mathrm{ECW}$ were observed in that period. For the time of 30 minutes after injection the $\mathrm{ECW}$ showed progressive increase in its values to the maximum of $7.26 \mathrm{dS} \mathrm{m}^{-1}\left(8.35 \mathrm{~g} \mathrm{~L}^{-1} \mathrm{~K}_{2} \mathrm{O}\right.$ and $\left.\mathrm{N}\right)$, this value being lower than that observed at the time of 20 minutes, showing a possible reduction of the $\mathrm{ECw}$ from the time of 30 minutes (Figure 2C).

According to Zanini, Villas Bôas and Feitosa Filho (2002), the fertilizer application time or fertigation time should be sufficient so that the whole dose required is correctly applied, in addition to extra time to allow the cleaning of the irrigation instruments, which may vary
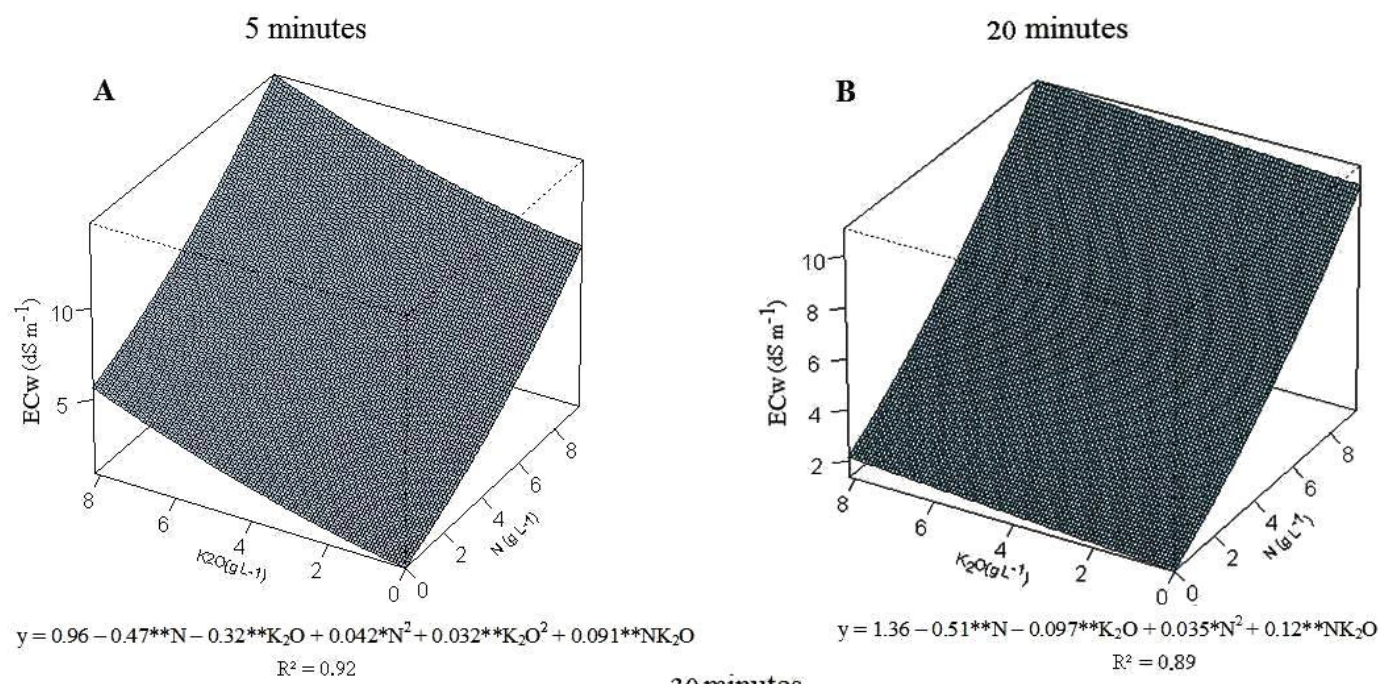

30 minutes

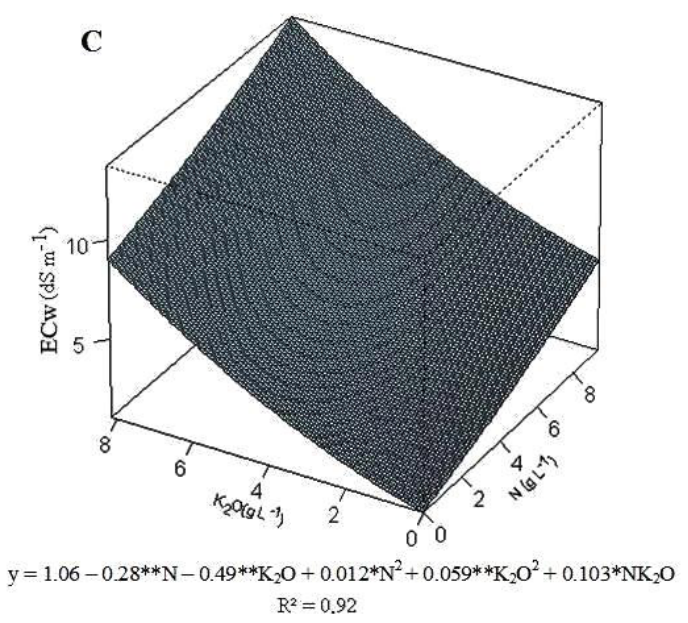

Figure 2: Analysis of dispersion of electrical conductivity in the irrigation water (ECw) subjected to different fertilizer doses measured at different times: $5 \mathrm{~min}(\mathrm{~A}), 20 \mathrm{~min}(\mathrm{~B}), 30 \mathrm{~min}(\mathrm{C})$ on the drip irrigation line.

** and * significant at 1 and $5 \%$ by t test respectively. 
from an hour or two. Sousa et al. (2011) stated that the fertigation time should not be less than 30 minutes because there might be a risk of low uniformity of distribution of the fertilizers over the area, affecting the development and productivity of the crop.

By assessing the uniformity of the irrigation system application (Table 2) in the different cycles studied, it was possible to see a reduction in the initial flow of the system in later growing cycles, but there was no reduction in water application efficiency. According to Favetta and Botrel (2001), the use of these equations proves to be potentially viable in post-implementation assessments of irrigation systems, because the choices of collection points for flow measurements are completely different between the concepts of emission uniformity and statistical uniformity. Regarding the application of fertilizers through the irrigation system studied, its efficiency was considered satisfactory, thus not compromising the use of fertigation during the experimental cycles.

In the monitoring of the nitrate concentration $\left(\mathrm{NO}_{3}\right)$ in the soil solution during the first growing cycle at the depths of $0.4 \mathrm{~m}$ (Figure 3A) and $0.6 \mathrm{~m}$ (Figure 3B), the nitrate concentrations were virtually constant until 73 days after production pruning (dapp). As of the 73 dapp there was an increase in $\mathrm{NO}_{3-}$ concentration at both depths, with values greater than $400 \mathrm{mg} \mathrm{L}^{-1}$ possibly due to low water demand by plants in this period, which contributed to increasing $\mathrm{NO}_{3}$ concentration in the soil solution.

In the second growing cycle there was a greater variability between the $\mathrm{NO}_{3 \text { - }}$ concentrations in comparison with the first cycle. At a depth of $0.4 \mathrm{~m}$ there were $\mathrm{NO}_{3-}$ concentrations greater than $1,000 \mathrm{mg} \mathrm{L}^{-1}$ throughout the growing cycle (Figure $3 \mathrm{C}$ ), reaching values greater than $3,000 \mathrm{mg} \mathrm{L}^{-1}$ at a depth of $0.6 \mathrm{~m}$ (Figure 3D), especially in the treatments with the highest $\mathrm{N}$ doses. However, the concentrations found in both depths at the end of the cycle were low, less than $100 \mathrm{mg} \mathrm{L}^{-1}$. Thus, part of the nitrate present in the soil solution was absorbed by the plants, and the other part was possibly lost by leaching. Hannam et al. (2013) in studies about nitrogen fertilization and controlled irrigation in $\mathrm{cv}$. Merlot vines observed that in sandy soils with low organic matter the time for applying $\mathrm{N}$ should be chosen carefully to enhance the efficiency of absorption of this nutrient for plants.

The third growing cycle started with only 57 days of rest after the harvest of the second cycle, with the nitrate concentration in the soil solution relatively low. The $\mathrm{NO}_{3-}$ concentration in the soil solution at a depth of $0.4 \mathrm{~m}$ (Figure 3E) stood relatively constant throughout the cycle studied, with the highest concentration, of $677 \mathrm{mg} \mathrm{L}^{-1}$, being reached 64 dapp. At a depth of $0.6 \mathrm{~m}$ (Figure $3 \mathrm{~F}$ ) there was an increase in nitrate concentrations, reaching values above $1,000 \mathrm{mg} \mathrm{L}^{-1}$ for the treatment with application of $120 \mathrm{~kg} \mathrm{ha}^{-1} \mathrm{~N}$. These results indicate that there was a greater nitrate concentration in the deeper layers of the soil, which reflects the effect of applying nitrogen fertilizers at high concentrations in the soil. Considering the effective depth of the wine vine root system of $0.6 \mathrm{~m}$ (Bassoi et al., 2007), it is possible that high nitrate concentrations have been lost by leaching, causing the contamination of the water table. However, Alcântara and Camargo (2010) in studies about nitrate movement in columns of horizontal soils claim that the movement of this ion is delayed in relation to the advancing of the wetting front.

In the analysis of variance for the nitrate in the soil solution response variable, it was possible to observe only the influence of the nitrogen dose factor at $1 \%$ probability by the $\mathrm{F}$ test at all depths studied $(0.4$ to $0.6 \mathrm{~m})$. The $\mathrm{K}_{2} \mathrm{O}$ dose factor and the $\mathrm{N} / \mathrm{K}_{2} \mathrm{O}$ interaction showed no effect on the variable studied. These results are similar to those obtained by Coelho et al. (2014), showing the high influence of nitrogen fertilizers on $\mathrm{NO}_{3-}$ concentration in the soil solution.

The regression analysis of the data shows a linear effect on the nitrate concentration in the soil solution in response to the nitrogen doses applied (Figure 4). In the first growing cycle at the depth of $0.4 \mathrm{~m}$ there was an increase of $1.19 \mathrm{mg} \mathrm{L}^{-1}$ in the $\mathrm{NO}_{3}$ concentration for each unit increase in the nitrogen dose applied to the soil (Figure 4A), while for the depth of $06 \mathrm{~m}$ the increase stood at $1.59 \mathrm{mg} \mathrm{L}^{-1}$ (Figure 4B).

Table 2: Assessment of the irrigation system during the 3 growing cycles for average flow rate (Q), Christiansen's uniformity coefficient (CUC), emission uniformity (EU), absolute emission uniformity (EUa), statistical uniformity (Us) and application efficiency (AE).

\begin{tabular}{ccccccc}
\hline Period & Average Q $\left(\mathrm{L} \mathrm{h}^{-1}\right)$ & CUC (\%) & EU & EUa & Us & AE \\
\hline 1st Cycle & 3.68 & 96.65 & 96.30 & 95.37 & 95.88 & 85.60 \\
2nd Cycle & 3.21 & 96.36 & 94.58 & 93.98 & 95.39 & 84.23 \\
3rd Cycle & 3.10 & 97.47 & 96.29 & 95.98 & 96.99 & 86.41 \\
\hline
\end{tabular}



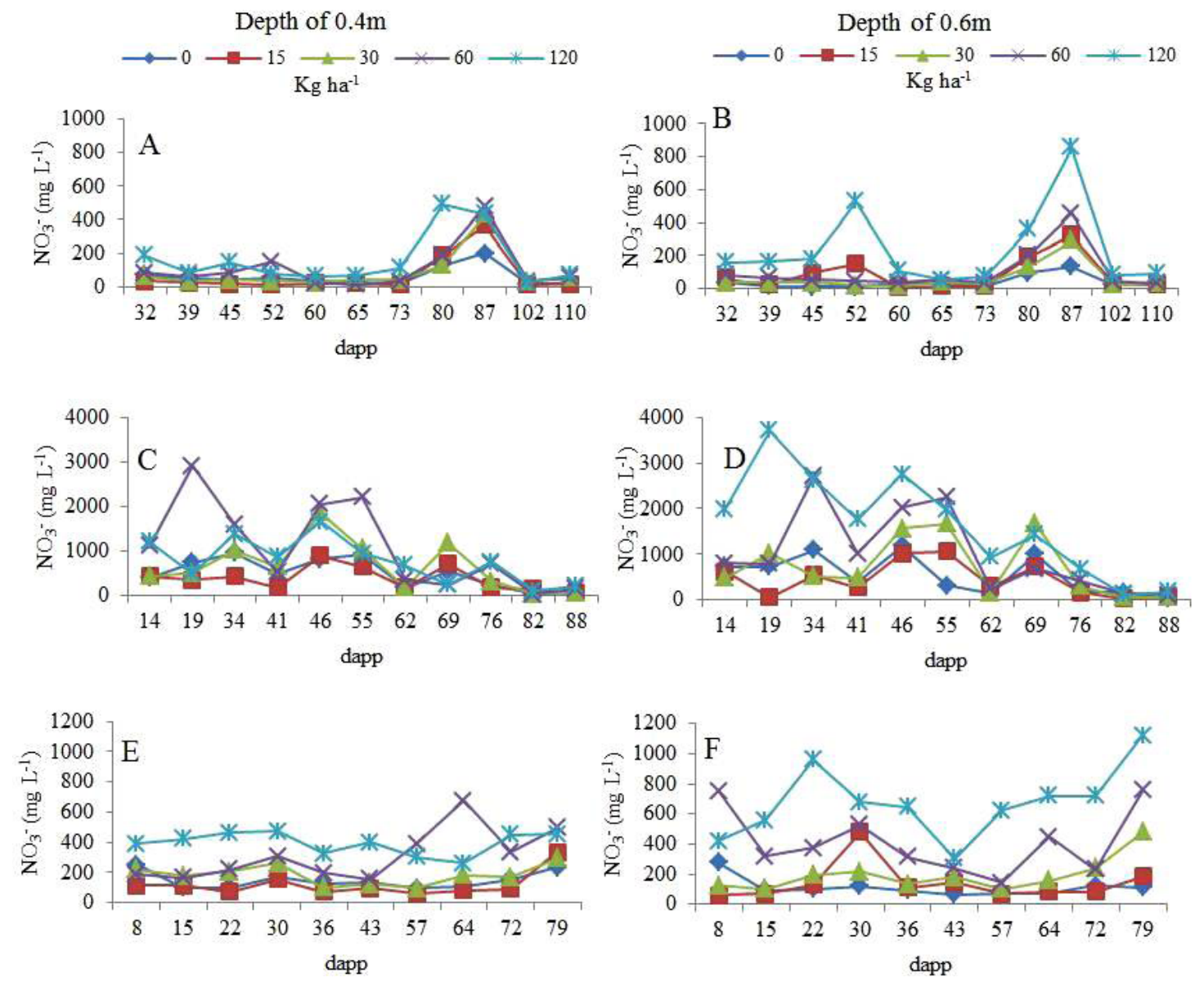

Figure 3: Nitrate concentration at soil depths of 0.4 and $0.6 \mathrm{~m}$, respectively, in the first ( $A$ and $B$ ), second ( $C$ and D) and third (E and F) wine vine growing cycles.

In the second growing cycle the $\mathrm{NO}_{3-}$ concentration at the depth of $0.4 \mathrm{~m}$ showed an increase of $3.64 \mathrm{mg} \mathrm{L}^{-1}$ (Figure 4C), while at the depth of $0.6 \mathrm{~m}$ (Figure 4D) the value was $14.69 \mathrm{mg} \mathrm{L}^{-1}$ at each unit increase in the nitrogen doses applied. In the third growing cycle there is once again a linear fit for the data obtained with increases of 2.39 and $5.38 \mathrm{mg} \mathrm{L}^{-1}$ for each unit increase in the nitrogen doses applied for the depths of $0.4 \mathrm{~m}$ (Figure 4E) and $0.6 \mathrm{~m}$ (Figure 4F), respectively. The results obtained corroborate those of Coelho, Andrade Neto and Barros (2014), who observed an increasing $\mathrm{NO}_{3-}$ concentration in the soil solution with the increase in the nitrogen fertilizer dose applied via fertigation in the banana crop.

The monitoring of ion potassium concentration in the soil solution in the first growing cycle showed, at a depth of $0.4 \mathrm{~m}$ (Figure $5 \mathrm{~A}$ ), low concentrations in $\mathrm{K}$ values, from 32 to 52 dapp; at 60 dapp there was an increase in $\mathrm{K}$ values for doses of $30\left(101.5 \mathrm{mg} \mathrm{L}^{-1}\right), 60\left(89.48 \mathrm{mg} \mathrm{L}^{-1}\right)$ and $120\left(195 \mathrm{mg} \mathrm{L}^{-1}\right) \mathrm{kg} \mathrm{ha}^{-1}$ of $\mathrm{K}_{2} \mathrm{O}$, and after this period concentration values stabilized, except for the dose of 60 $\mathrm{kg} \mathrm{ha}^{-1}$, at $87 \mathrm{dapp}$, which showed $\mathrm{K}$ concentration of 191.8 $\mathrm{mg} \mathrm{L}^{-1}$. At the depth of $0.6 \mathrm{~m}$ (Figure $5 \mathrm{~B}$ ) $\mathrm{K}$ concentrations were lower than those obtained at the depth of $0.4 \mathrm{~m}$, increasing only at 52 dapp $\left(272.8 \mathrm{mg} \mathrm{L}^{-1}\right)$ In general, the potassium concentration did not exceed $200 \mathrm{mg} \mathrm{L}^{-1}$.

In the second growing cycle, at the depth of $0.4 \mathrm{~m}$ (Figure 5C), the $\mathrm{K}$ concentration showed high values in the period between 39 and 46 dapp; after this period there was a reduction in the concentration of the ion, possibly due to the consumption of the plant associated with the crop evapotranspiration rates (kc equal to 1,0 ) with greater absorption of the soil solution. At the depth of $0.6 \mathrm{~m}$ (Figure 5D) there was an increase in $\mathrm{K}$ concentration at 19 dapp in the treatment with higher dosage; thus, it was 
possible to observe the movement of this ion between the layers studied; however, over the cycle few oscillations were observed in the treatments. In general, the potassium concentration did not exceed $200 \mathrm{mg} \mathrm{L}^{-1}$ (Figure 5E and F). According to Zanini, Villas Bôas and Feitosa Filho (2002), potassium moves with limitation through the soil profile, where losses by leaching are low even in sandy soils with low CEC.

In the third growing cycle, $\mathrm{K}$ concentrations barely exceeded $120 \mathrm{mg} \mathrm{L}^{-1}$, being significantly reduced in the treatments with higher doses $\left(60\right.$ and $120 \mathrm{~kg} \mathrm{ha}^{-1}$ of $\mathrm{K}_{2} \mathrm{O}$ ). According to Duarte, Pereira and Korndofer (2013) when studying the leaching of potassium in soils under different sources of fertilizers, the highest leaching levels occurred with sources of $\mathrm{KCl}$, but
Laurindo et al. (2010) in studies about the distribution of this nutrient in the soil via fertigation observed that the $\mathrm{K}$ concentration in the soil is reduced when outside the range of the wet bulb.

In the analysis of variance for the $\mathrm{K}$ variable, a significant effect of the potassium dose factor was observed for all growing cycles and soil depths studied at $1 \%$ probability, except in the second growing cycle and at the depth of $0.6 \mathrm{~m}$. In studies about the dynamics of nutrients in fertigated citrus orchard, Souza et al. (2012) also observed an increase in $\mathrm{K}$ concentration in the soil solution as NPK doses applied through fertigation increased, but the availability of this nutrient may vary significantly depending on the phenological phase of the vine crop (Silva et al., 2014).
Depth of $0.4 \mathrm{~m}$
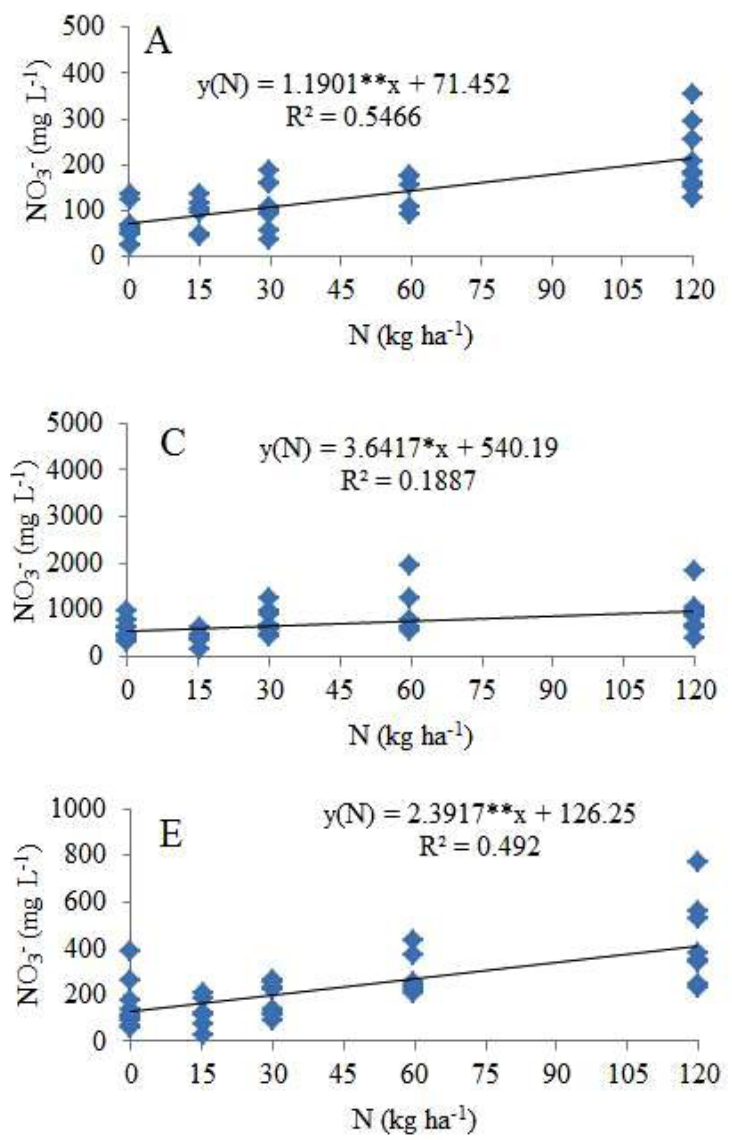

Depth of $0.6 \mathrm{~m}$
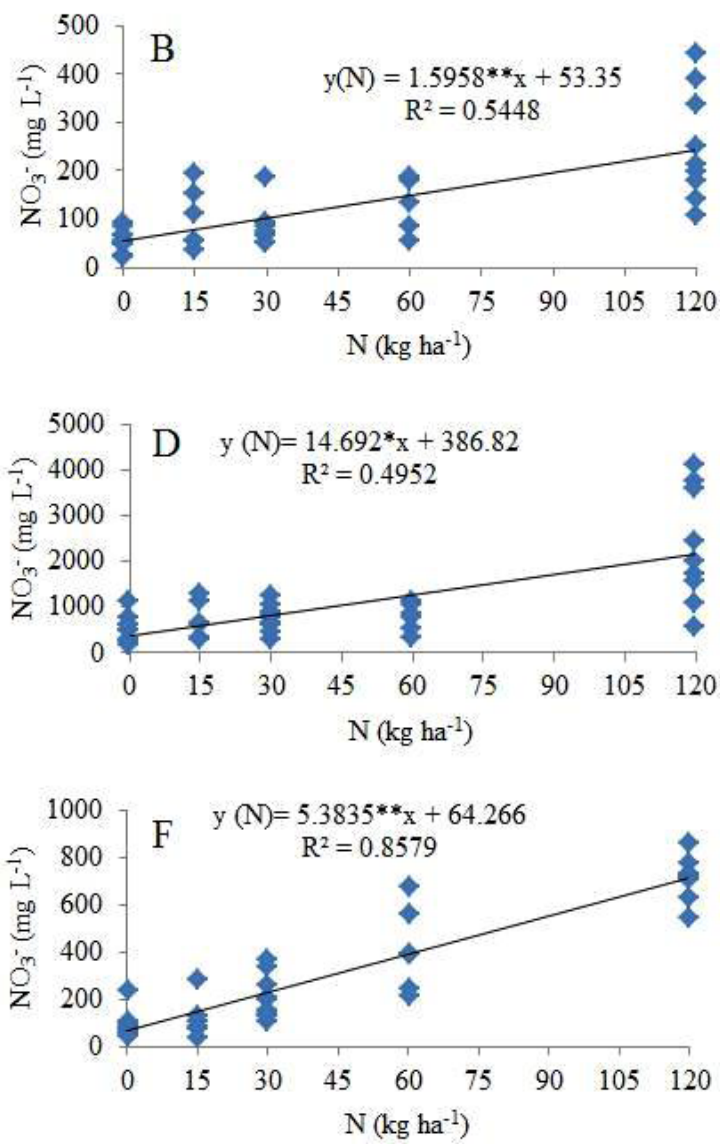

Figure 4: Regression equations for the average nitrate concentration in the soil solution at the depths of 0.4 and $0.6 \mathrm{~m}$, respectively, in the first ( $A$ and $B)$, second $(C$ and $D)$ and third ( $E$ and $F$ ) wine vine growing cycles.

** and * significant at 1 and $5 \%$ by the $t$ test respectively. 

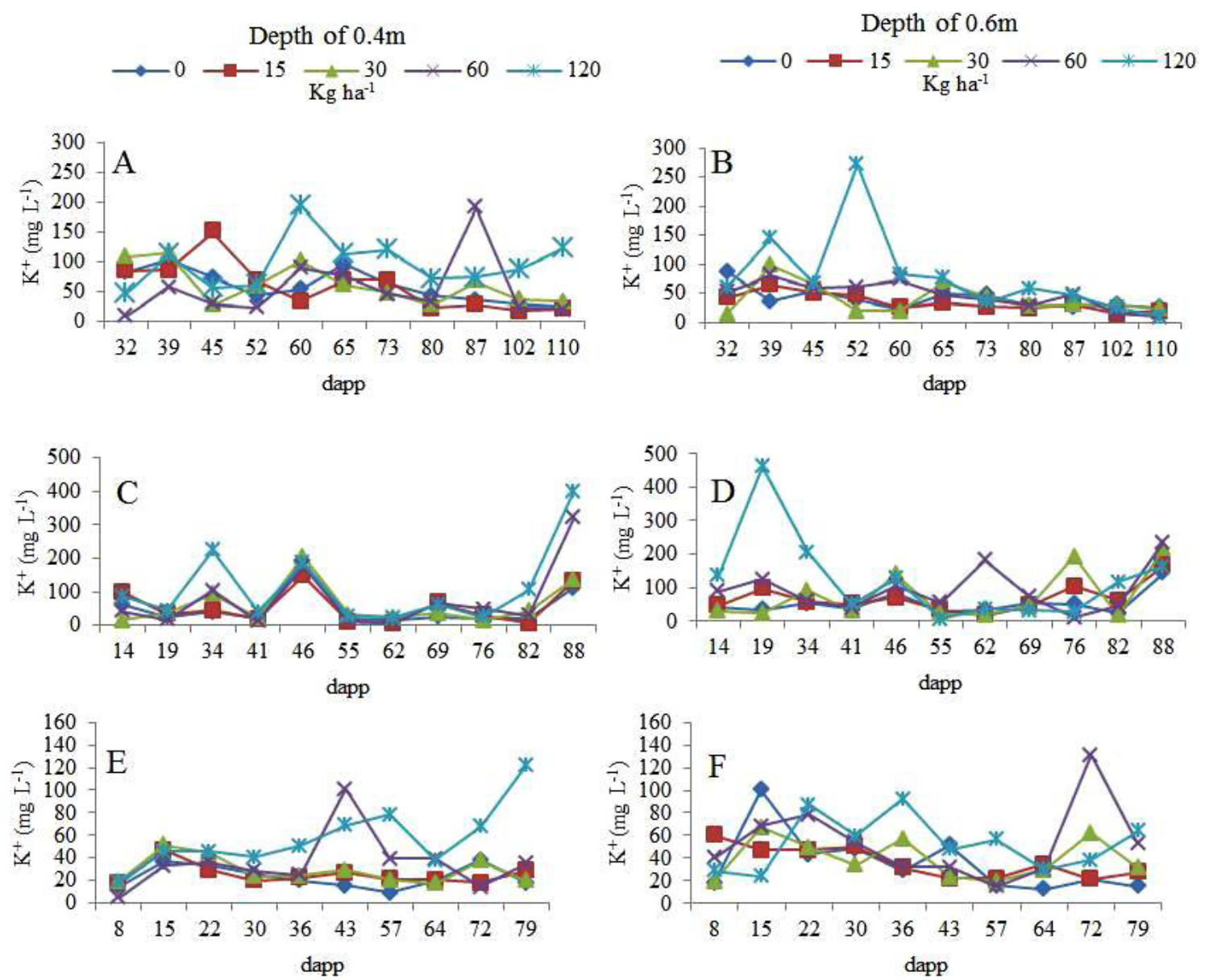

Figure 5: Potassium concentration at the soil depths of 0.4 and $0.6 \mathrm{~m}$, respectively, in the first (A and $B$ ), second $(B$ and $C)$ and third ( $D$ and $E$ ) wine vine growing cycles.

The regression analysis of the concentration of the potassium ion had a linear fit according to the potassium doses applied (Figure 6). In the first growing cycle there was an increase of $0.3253 \mathrm{mg} \mathrm{L}^{-1}$ and $0.2544 \mathrm{mg} \mathrm{L}^{-1}$ for each unit increase in the $\mathrm{K}_{2} \mathrm{O}$ doses used, at the depths of $0.4 \mathrm{~m}$ (Figure 6A) and $0.6 \mathrm{~m}$ (Figure 6B), respectively. In the second cycle, at the depth of $0.4 \mathrm{~m}$ (Figure 6C) there was an increase of $0.6276 \mathrm{mg} \mathrm{L}^{-1}$ for each unit increase in the $\mathrm{K}_{2} \mathrm{O}$ doses studied. In the third growing cycle the increase in $\mathrm{K}$ concentration was $0.3219 \mathrm{mg} \mathrm{L}^{-1}$ at the depth of $0.4 \mathrm{~m}$ (Figure $6 \mathrm{E}$ ), and $0.3311 \mathrm{mg} \mathrm{L}^{-1}$ at the depth of $0.6 \mathrm{~m}$ (Figure 6D). The linear effect presented in this study corroborate with those of Silva et al. (2014), in studies about $\mathrm{K}_{2} \mathrm{O}$ doses $\left(0,20,40,80\right.$ and $\left.160 \mathrm{~kg} \mathrm{ha}^{-1}\right)$ applied via fertigation to Syrah vines, in which these authors observed higher values of $\mathrm{K}$ ion in the highest $\mathrm{K}_{2} \mathrm{O}$ doses applied.
The electrical conductivity of the soil solution increased with the $\mathrm{N}$ doses; there was interaction with $\mathrm{K}_{2} \mathrm{O}$ only at the depth of $0.4 \mathrm{~m}$ in the second growing cycle. These results reinforce the influence of nitrogen fertilizers on the soil solution, as observed by Coelho, Andrade Neto and Barros (2014) and Souza et al. (2012). According to the analysis of dispersion of data on electrical conductivity in the soil solution (Figure 7), the best fit model was the linear one for all growing cycles and depths studied.

For the first growing cycle there was an increase in EC with the unit increase in the nitrogen doses studied, with values of 0.0005 and $0.0006 \mathrm{dS} \mathrm{m}^{-1}$ at the depths of $0.4 \mathrm{~m}$ (Figure 7A) and $0.6 \mathrm{~m}$ (Figure 7B), respectively. In the second growing cycle the increase in electrical conductivity was respectively $0.0009 \mathrm{dS}$ $\mathrm{m}^{-1}$ and $0.001 \mathrm{dS} \mathrm{m}^{-1}$ for the depth of $0.4 \mathrm{~m}$ (Figure 7C) and $0.6 \mathrm{~m}$ (Figure 7D). For the third growing cycle, 
increases of 0.0005 and $0.0007 \mathrm{dS} \mathrm{m}^{-1}$ were observed at the depths of $0.4 \mathrm{~m}$ (Figure 7E) and $0.6 \mathrm{~m}$ (Figure $7 F)$, respectively, for each unit increase in the nitrogen doses applied via fertigation.

The elevation in EC in the soil solution with the increase in the application of fertilizers should be monitored carefully, since applying nutrients in successive growing cycles may raise EC undesirably, affecting the yield of crops (Silva; Klar; Silva, 2015); for this reason, the use of porous cup extractors assist in the management of fertigation and can prevent soil salinity problems (Silva, 2014).
Depth of $0.4 \mathrm{~m}$
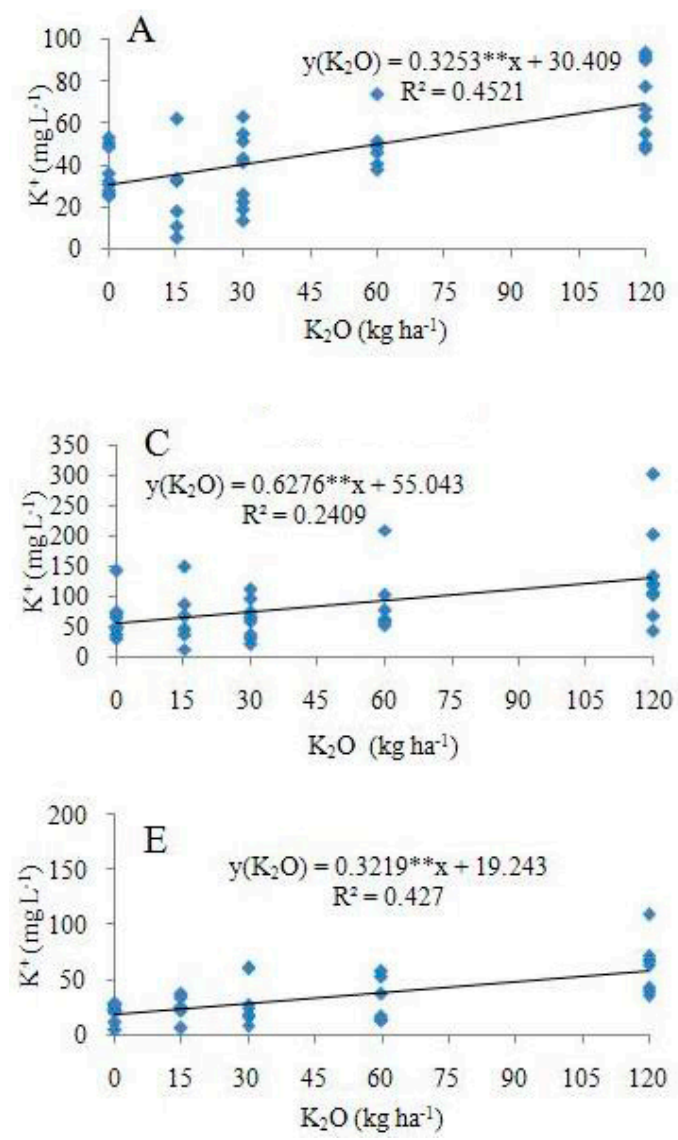

Depth of $0.6 \mathrm{~m}$
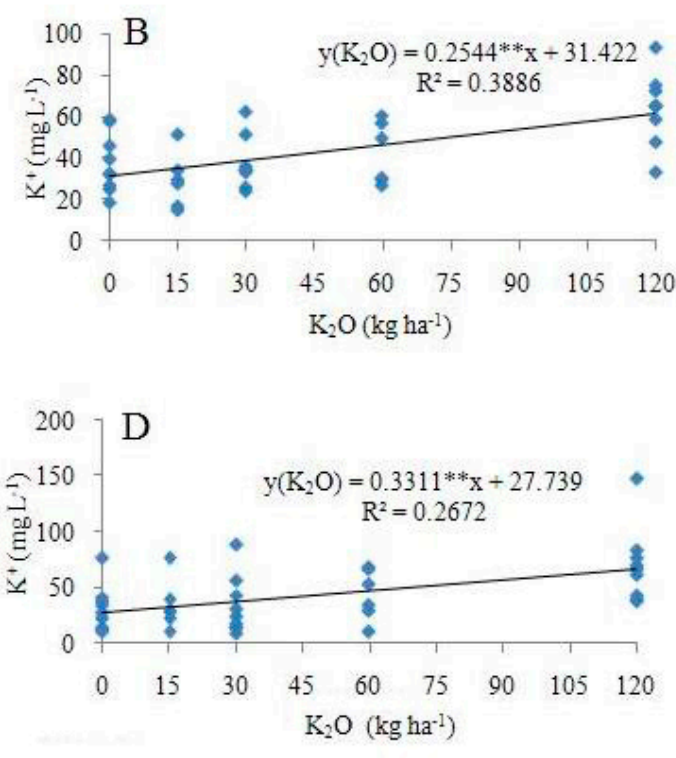

Figure 6: Regression equations for potassium concentration in the soil solution at the depths of 0.4 and $0.6 \mathrm{~m}$, respectively, in the first (A and $B$ ), second $(C)$ and third ( $D$ and $E$ ) wine vine growing cycles.

** and * significant at 1 and $5 \%$, by the $t$ test respectively. 
Depth of $0.4 \mathrm{~m}$
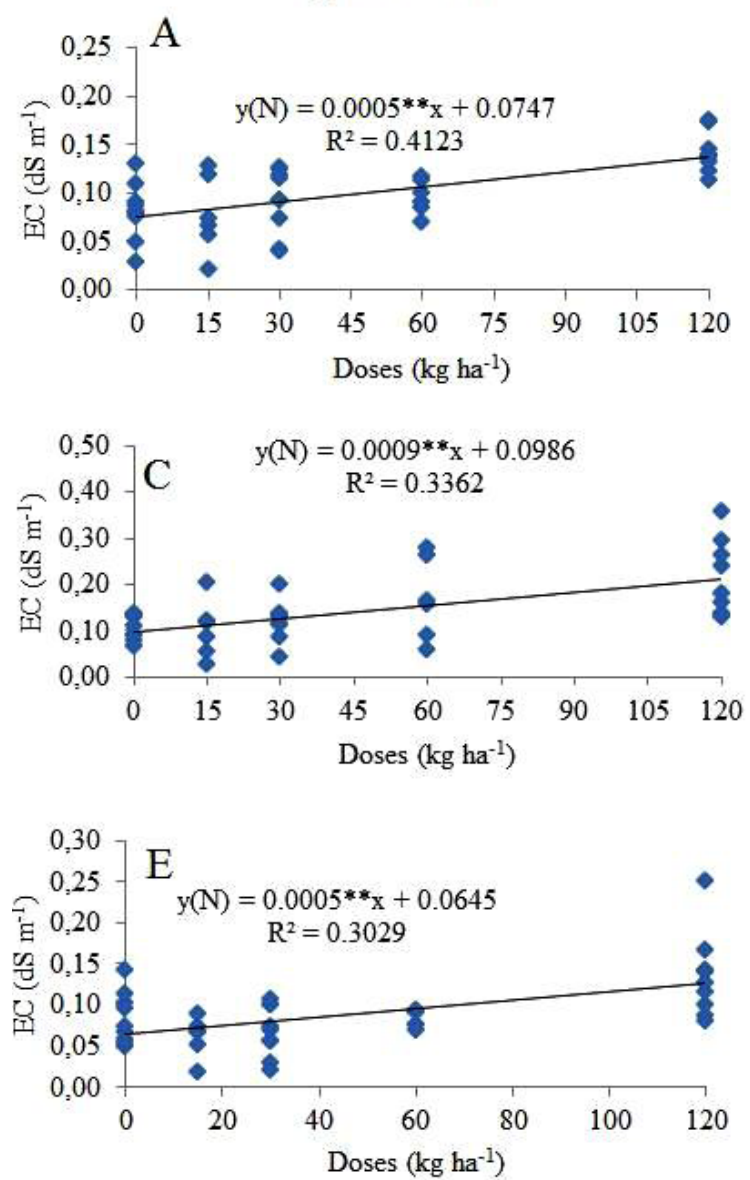

Depth of $0.6 \mathrm{~m}$
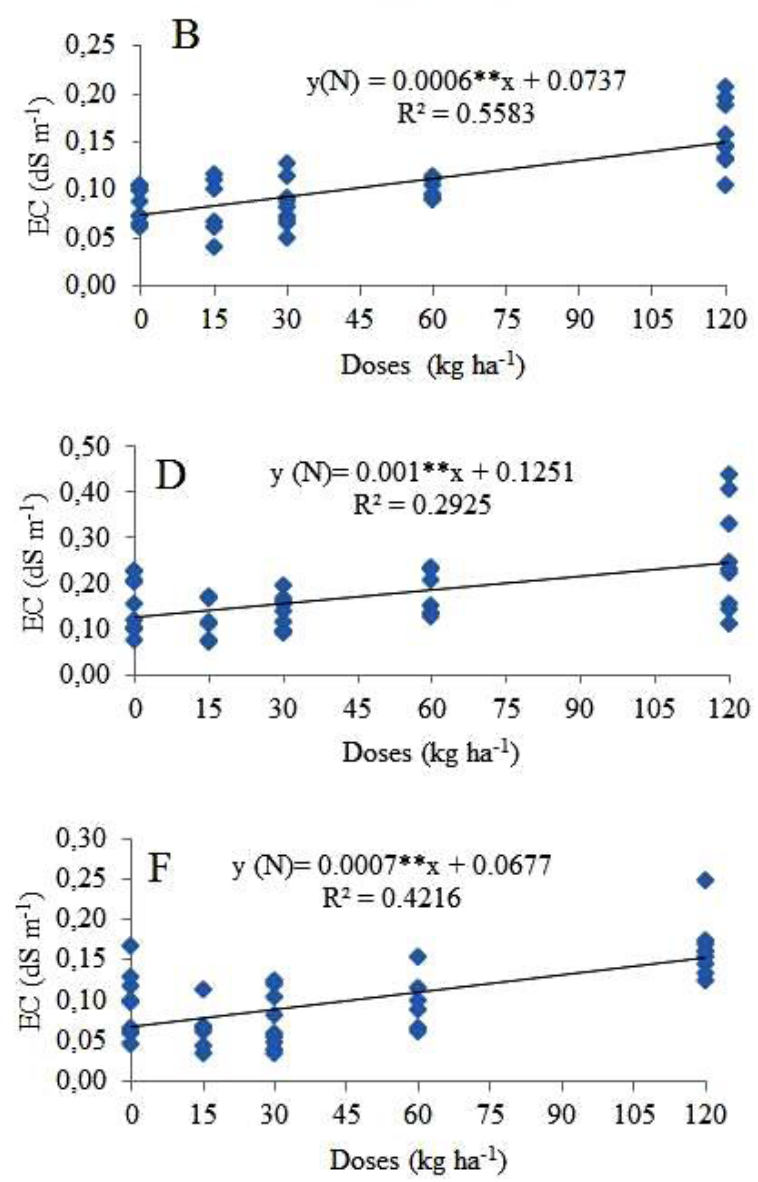

Figure 7: Regression equations for electrical conductivity in the soil solution at the depths of 0.4 and $0.6 \mathrm{~m}$, respectively, in the first $(A$ and $B)$, second ( $C$ and $D)$ and third ( $E$ and $F)$ wine vine growing cycles.

** and * significant at 1 and $5 \%$, by the t test respectively.

\section{CONCLUSIONS}

The distribution of fertilizers was influenced only by their concentrations in irrigation water. Neither the injection time or distance of the emitter from the beginning of drip irrigation line influenced the electrical conductivity in the water.

The increase in nitrogen and potassium concentrations in the irrigation water increased the availability of nitrate and potassium in the soil solution. The nitrogen fertilizer increasingly influenced the electrical conductivity in the soil solution. The highest nitrate and potassium concentrations were observed in the second wine vine growing cycle at both depths studied, with a significant potential for leaching losses of nitrate.

\section{REFERENCES}

ALCÂNTARA, M. A. K.; CAMARGO, O. A. Movimentação de nitrato em horizonte superficial e subsuperficial de Latossolo e Nitossolo com cargas variáveis. Pesquisa Agropecuária Brasileira, 45(1):81-88, 2010.

ALLEN, R. G. et al. Crop evapotranspiration: guidelines for computing crop water requirements. Rome: FAO, (Irrigation and Drainage Paper, 56), 1998. 300p

ARAÚJO, A. R. et al. Movimentação de nitrato e amônio em colunas de solo. Ciência e Agrotecnologia, 28(3):537-541, 2004.

BASSOI, L.H. etal. Preliminary results of a long-term experiment about RDI and PRD irrigation strategies in winegrapes in São Francisco Valley, Brazil. Acta Horticulturae, 754(1):275-282, 2007. 
COELHO, E. F.; ANDRADE NETO, T. M.; BARROS, D. Concentration of injetion solution and its effects on soil and on yield of fertirrigated banana cv. Terra Maranhão. Engenharia Agrícola, 34(6):1104-1113, 2014.

COELHO, E. F. et al. Concentração de nitrato no perfil do solo fertigado com diferentes concentrações de fontes nitrogenadas. Revista Brasileira de Engenharia Agrícola e Ambiental, 18(3):263-269, 2014.

CUNHA, F. N. et al. Uniformidade de aplicação de fertilizantes sob um sistema de gotejamento subsuperficial. Revista Brasileira de Agricultura Irrigada, 8(5):391-402, 2014.

DUARTE, I. N.; PEREIRA, H. S.; KORNDOFER, G. H. Lixiviação de potássio proveniente do termopotássio. Pesquisa Agropecuária Tropical, 43(2):195-200, 2013.

FAVETTA, G. M.; BOTREL, T. A. Uniformidade de sistemas de irrigação localizada: validação de equações. Scientia Agricola, 58(2):427-430, 2001.

HANNAM, K. D. et al. The concentration of yeast assimilable nitrogen in Merlot grape juice is increased by $\mathrm{N}$ fertilization and reduced irrigation. Canadian Journal Plant Science, 93(1):37-45, 2013.

LAURINDO, V. T. et al. Padrão de distribuição de $\mathrm{K}^{+}, \mathrm{Ca}^{++}$, $\mathrm{Mg}^{++}$e $\mathrm{P}$ no solo de um pomar de citros em função da fertirrigação. Engenharia Agrícola, 30(5):909-921, 2010.

LITTEL, R.C.; MOTT, G.O. Computer assisted design and analysis of response surface experiments in agronomy. Soil and Crop Society of Florida Proceedings, 34(1):94-97, 1975.

NESTHED, N. et al. Evaluation of different fertigation equipments and the hydraulic performance of the drip fertigation system. Journal of Agriculture Science, 1(1):12-17, 2013.

RAMOS, M. R. et al. Evaluation of nitrate leaching in a vulnerable zone: effect of irrigation water and organic manure application. Spanish Journal of Agricultural Research, 9(3):924-937, 2011.

R Development Core Team. R: A language and environment for statistical computing: reference index version 2.8.0. Vienna foundation for statistical computing. Available in: <http://www.r-project.org/>. Access in: 2012.
ROCHA, M. G.; BASSOI, L. H.; SILVA, D. J. Atributos do solo, produção da videira 'Syrah' irrigada e composição do mosto em função da adubação orgânica e nitrogenada. Revista Brasileira de Fruticultura, 37(1):198-207, 2015.

SILVA, A. O. A fertirrigação e o processo de salinização de solos em ambiente protegido. Nativa, 2(3):180-186, 2014.

SILVA, A. O.; KLAR, A. E.; SILVA, E. F. F. Manejo da fertirrigação e salinidade do solo no crescimento da cultura da beterraba. Engenharia Agrícola, 35(2):230-241, 2015.

SILVA, D. J. et al. Adubação orgânica e fertirrigação potássica em videira 'Syrah' no Semiárido. Irriga, 1(1):168-178, 2014.

SILVA, E. F. F. et al. Utilização de testes rápidos e extratores de solução do solo na determinação de nitrato e potássio. Engenharia Agrícola, 23(3): 460-467 2003.

SIQUEIRA NETO, M. et al. Mineralização e desnitrificação do nitrogênio do solo sob sistema de plantio direto. Bragantia, 69 (4): 923-936, 2010.

SOUSA, V. F. et al. Manejo da fertirrigação em fruteiras e hortaliças. In: SOUSA, V. F. et al. (Coord). Irrigação e fertirrigação em fruteiras e hortaliças. Brasília: Embrapa Informação Tecnológica, 2011. v.1, p.317-337.

SOUZA, E. R. et al. Comparação de métodos de extração da solução do solo. Revista Brasileira de Engenharia Agrícola e Ambiental, 17(5):510-517, 2013.

SOUZA, T. R. et al. Dinâmica de nutrientes na solução do solo em pomar fertirrigado de citros. Pesquisa Agropecuária Brasileira, 47(6):846-854, 2012.

TERRA, M. M. Nutrição e adubação da videira. In: BOLIANI, A. C.; CORRÊA, L. de S. (Ed.). Cultura de uvas de mesa: do plantio à comercialização. Ilha Solteira: Unesp-Fapesp, 2001, v.1, 149-176p.

ZANINI, J. R.; VILLAS BÔAS, R. L.; FEITOSA FILHO, J. C. Uso e manejo da fertirrigação e hidroponia. Jaboticabal: Funep, 2002. 65p. 